Article

\title{
Organocatalytic Enantioselective Epoxidation of Some Aryl-Substituted Vinylidenebisphosphonate Esters: On the Way to Chiral Anti-Osteoporosis Drugs
}

\author{
Andrea Chiminazzo, Laura Sperni, Alessandro Scarso and Giorgio Strukul * \\ Dipartimento di Scienze Molecolari e Nanosistemi, Università Ca' Foscari Venezia, via Torino 155, 30170 Venezia \\ Mestre, Italy; andrea.chiminazzo@unive.it (A.C.); Lsperni@hotmail.com (L.S.); alesca@unive.it (A.S.) \\ * Correspondence: strukul@unive.it; Tel.: +39-041-234-8931 \\ Academic Editor: Veronique Nardello-Rattaj \\ Received: 18 January 2017; Accepted: 13 March 2017; Published: 20 March 2017
}

\begin{abstract}
The synthesis of a new class of epoxide derivatives from prochiral vinylidene bisphosphonate (VBP) precursors is reported using hydrogen peroxide as the terminal oxidant. The reaction is carried out using a series of possible organic activators having a basic character, with the best results being observed using quinine and sparteine. These activators not only provide from good to excellent epoxide yields with a large variety of VBPs, but also interesting enantioselectivities in the $67 \%-96 \%$ ee range, at least in the case of the $\mathrm{Ph}$ and $m-\mathrm{MeO}-\mathrm{Ph}$ VBP derivatives, opening the way to a number of chiral anti-osteoporosis potentially active pharmaceutical ingredients.
\end{abstract}

Keywords: bisphosphonates; epoxidation; hydrogen peroxide; enantioselectivity; quinine; sparteine

\section{Introduction}

Osteoporosis is a skeleton disease characterized by loss of bone mass and deterioration of tissue micro-architecture that leads to bone fragility and an increase in fracture risk [1]. Nowadays, it affects hundreds of millions of elderly individuals worldwide (especially women) with a severe impact on their quality of life and significant social costs for medical treatments. The future perspectives, especially in the western world, are even worse because of the rapid increase of the elderly population $[2,3]$.

Bisphosphonates (BPs) are currently the major class of drugs used for the treatment of both osteoporosis and other diseases characterized by increased bone resorption [4,5]. BPs are chemical analogs of biologically occurring pyrophosphates (major mineral constituents of bone) and they have a strong binding capacity to metal ions (e.g., calcium) as well as a very high affinity for the bone mineral (Figure 1).<smiles>O=P(O)(O)OP(=O)(O)O</smiles>

A<smiles>[R7]C([R7])(P(=O)(O)O)P(=O)(O)O</smiles>

Figure 1. Pyropshosphoric acid (A) and a generic structure of a bisphosphonic acid (B).

BPs have been used as anti-osteoporosis drugs for the past 40 years and despite a relative increase in molecular complexity and potency over the years, the structures of the commercial drugs are still relatively simple. These molecules do not possess the complexity and structural variety necessary to cope with their therapeutic mechanism of action [6-9], to improve their poor bioavailability [10], or to tackle other related application fields where BPs promise interesting results such as, e.g., as anti-arthritis 
and anti-bone tumor drugs [4]. In this respect, the major limit seems to be the lack of reliable synthetic methods to prepare a wider range of complex molecules and tune the tridimensional neighborhood around the BP group. For example, even though the different biological response to molecules having different stereoisomerism is a very well-known concept, the lack of enantioselective synthetic methods has so far hampered the synthesis of chiral BPs where very few examples have been reported in the literature [11-13], with only one example of an enantio-enriched BP having been biologically tested, observing a 24-fold difference in activity between the enantiomers [14]. This situation reflects the problems of dealing synthetically with molecules having a bisphosphonate group which induces (i) a strong electrophilicity on the central $\mathrm{C}$ atom and eventually on adjacent moieties; (ii) a significant steric hindrance leading in many cases to limited accessibility and poor reactivity; and (iii) the capacity of strongly binding metal ions, thereby inactivating catalysts in transition metal-catalyzed reactions.

A useful synthetic approach allowing the formation of a broad range of BPs is based on vinylidenebisphosphonate precursors (VBPs) as starting materials [15-18]. The application of a series of enantioselective catalytic reactions based on the use of a variety of nucleophilic reagents towards these precursors opens the way to the possibility of obtaining a wide range of structurally complex $\mathrm{BPs}$, and in principle the opportunity to verify the different behaviors of the synthesized enantiomers. Among the different possibilities, enantioselective epoxidation represents a key technology because the oxirane ring can be easily opened by different types of reactants, allowing the preparation of chiral 1,2-disubstituted derivatives [19].

As a follow-up to our previous work in this area $[15,20,21]$, in this paper we report the epoxidation of a series of monosubstituted prochiral VBPs using different possible oxidants and catalyzed by enantiopure organocatalysts, observing, in some specific cases, interesting levels of stereoselective induction. We also report some subsequent attempts to open the oxirane ring to lead to the formation of enantioenriched BPs having an -OH group between the two $\mathrm{P}$ atoms, a feature that improves their affinity with hydroxyapatite [22], i.e., the major mineral constituent of bone.

\section{Results and Discussion}

A series of monosubstituted VBP precursors has been synthesized following the method outlined by Lehnert and other groups [23-26] which consists of the addition of an aldehyde to methylene bisphosphonate tetraethyl ester (MBP) catalyzed by $\mathrm{TiCl}_{4}$ in the presence of a base (Scheme 1) giving, in most cases, from good to excellent yields. As shown, the reaction proceeds well with aromatic aldehydes, whereas with aliphatic aldehydes or ketones it leads to only poor yields.

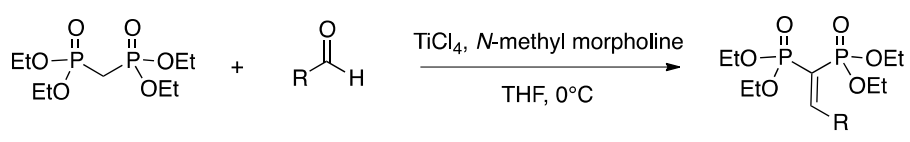
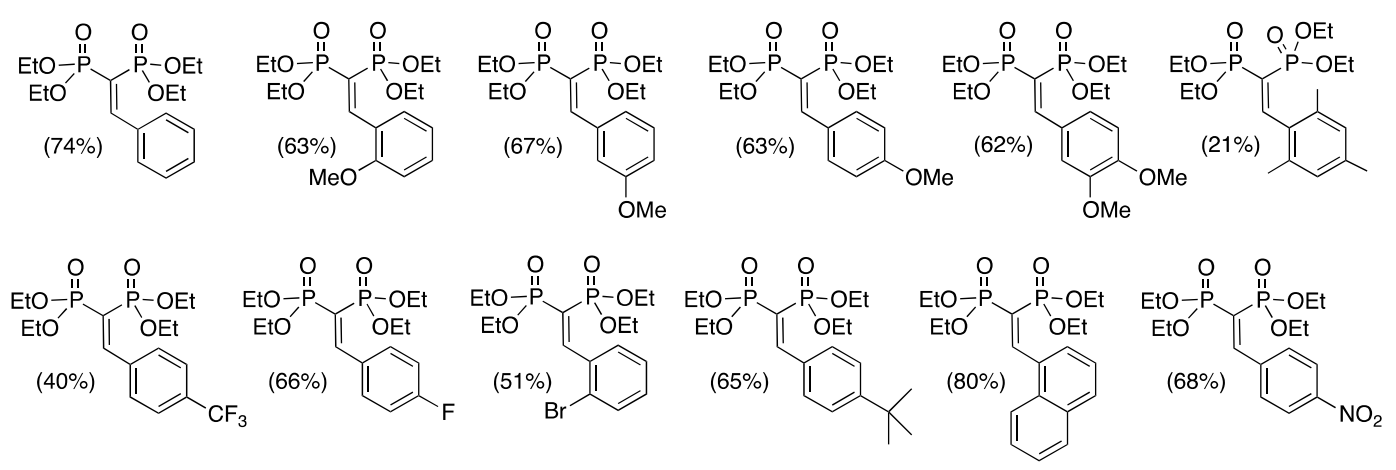

Scheme 1. Synthesis of VBP precursors. Isolated yields of the individual compounds are given in parentheses. 
The epoxidation of the electron-poor $\mathrm{C}=\mathrm{C}$ double bond $[27,28]$ was carried out, adapting to the case of prochiral BPs the classical Weitz-Scheffer reaction for the epoxidation of $\alpha, \beta$-unsaturated aldehydes, consisting of the use of hydrogen peroxide as the oxidant under basic conditions [29]. The use of $\mathrm{H}_{2} \mathrm{O}_{2}$ is recommended due to its highly environmentally acceptable character [30] and involves the nucleophilic attack of $\mathrm{HOO}^{-}$generated in situ to the electron-poor $\mathrm{C}=\mathrm{C}$ double bond. Initially the epoxides were synthesized in the racemic form from the VBPs shown in Scheme 1, using $\mathrm{NaOH}$ as the base to provide suitable amounts of material to perform the enantiomer separation, using chiral HPLC for the subsequent ee evaluation. The reaction was carried out in $\mathrm{MeOH}$ at room temperature and led to excellent conversions in most cases. All products were characterized by NMR and mass spectrometry.

As a typical example, the ${ }^{1} \mathrm{H}$ NMR spectrum of PPhO (see Supplementary Material, Figure S2) shows a series of features, namely: (i) a typical triplet at $4.69 \mathrm{ppm}\left({ }^{3} \mathrm{~J}_{\mathrm{H}-\mathrm{P}} 5.0 \mathrm{~Hz}\right)$ attributed to the oxiranic proton coupling with two non-equivalent $\mathrm{P}$ atoms but with almost equivalent ${ }^{3} \mathrm{~J}_{\mathrm{H}-\mathrm{P}}$ coupling constants; (ii) the signals attributed to the ester groups, i.e., the $-\mathrm{CH}_{2}-$ multiplet at $4.0 \mathrm{ppm}$ and four different signals for $-\mathrm{CH}_{3}$ at $1.41 \mathrm{ppm}$ and $1.13 \mathrm{ppm}$ due to the diastereotopic environments of the ester moieties derived by the presence of the stereocenter in the molecule; (iii) the ${ }^{31} \mathrm{P}\left\{{ }^{1} \mathrm{H}\right\}$ NMR spectrum showing two different doublets due to the diastereotopic environment of the $\mathrm{P}$ atoms. The mass spectrum (see Supplementary Materials, Figure S3) shows a very weak peak at $392 \mathrm{~m} / \mathrm{z}$ corresponding to the molecular ion of the product, thus providing a further confirmation of the structure of the product.

The stereoselective version of the epoxidation reaction was first tested on the phenyl-substituted derivative (PPh) in the presence of a wide range of possible activators and oxidants. The enantioselective oxidation of $\alpha, \beta$-unsaturated aldehydes has been the subject of numerous investigations in the past and was successfully accomplished both by organocatalysts by, e.g., Wynberg and coworkers using quininium salts [31] and by Julià and Colonna using poly-L-alanine [32] as well as by metal complexes, namely of Pt, reported by our group [33], or of $\mathrm{Y}$, reported by Shibasaki and coworkers [34].

Initial tests with our original [(chiraphos) $\left.\mathrm{Pt}\left(\mathrm{C}_{6} \mathrm{~F}_{5}\right)\left(\mathrm{H}_{2} \mathrm{O}\right)\right](\mathrm{OTf})$ catalyst [33] were totally unsuccessful, probably because the bisphosphonate unit binds to the metal efficiently, preventing the coordination of the $\mathrm{C}=\mathrm{C}$ double bond. So we reverted to a series of chiral organocatalysts (Scheme 2) able to activate either the substrate via hydrogen bonding $((R)$-binaphthol, $(R)$-mandelic acid, L-proline) or hydrogen peroxide used as the oxidant increasing its nucleophilicity by deprotonation (L-proline, (S)-dinaphthyl-2-pyrrolidinmethanol, (S)-1-benzyl-3-pyrrolidnol, hydroquinidine 4-chlorobenzoate, quinine, sparteine). These were tested towards PPh under mild conditions (Scheme 2) and the results obtained are summarized in Table 1.

As can be seen in Table 1, the use of catalysts being either Brønsted acidic or able to activate the substrate via hydrogen bonding (entries 1,2) is completely ineffective, whereas the nucleophilic activation of the oxidant produces either no or very moderate effects when using secondary amines (entries 3,4). Somehow, expectedly, higher yields were observed in the presence of tertiary amines such as quinine and sparteine. The absence of $-\mathrm{OH}$ groups capable of stabilizing the nucleophilic oxidant formed as in Figure 2 had a dramatic effect on the reaction yield. Compare, for example, the behavior of quinine (entry 7) which gives a $73 \%$ yield, with a very similar activator but modified with a $p$-Cl-benzoate ester moiety (entry 6) which results almost completely inactive. Interestingly, the absence of activity observed with benzyl-pyrrolidinol seems to indicate that basicity and the presence of an $\mathrm{OH}$ group is per se an insufficient condition because a critical distance between $\mathrm{N}$ and $\mathrm{OH}$ is necessary to favor the approach of the oxidant via hydrogen bonding (Figure 2). The drop in conversion observed with hydroquinidine 4-chlorobenzoate could also be the result of a higher steric hindrance in the catalyst. The sensitivity of this system to steric factors is demonstrated also by the poor but not null conversion observed with (S)-dinaphthyl-2-pyrrolidinmethanol, which is structurally similar to quinine, and also exploring the scope of the reaction (vide infra). 

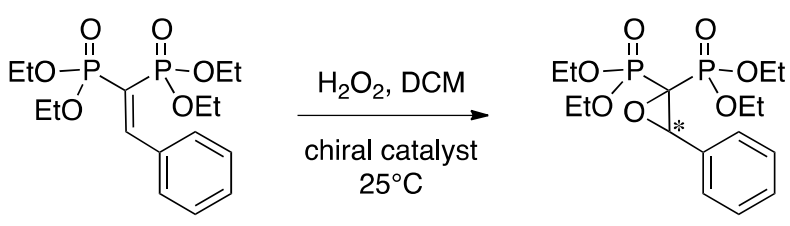<smiles>Oc1ccc2ccccc2c1-c1c(O)ccc2ccccc12</smiles>

(R)-binaphthol<smiles>O[C@H]1CCN(Cc2ccccc2)C1</smiles>

(S)-1-benzyl-3-pyrrolidinol<smiles>CC(C(=O)O)c1ccccc1</smiles>

(R)-mandelic acid<smiles>O=C(O)C1CCCN1</smiles>

L-proline<smiles>OC(c1ccc2ccccc2c1)(c1ccc2ccccc2c1)C1CCCN1</smiles>

(S)-dinaphthyl-2-pyrrolidinmethanol<smiles>CCC1C[C@@H](C(OC(=O)c2ccc(Cl)cc2)c2ccnc3ccc(OC)cc23)N2CCC1CC2</smiles>

hydroquinidine 4-chlorobenzoate<smiles>C=CC1CC2CCN1C2[C@H](O)c1ccnc2ccc(OC)cc12</smiles>

quinine

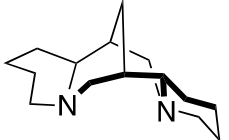

sparteine

Scheme 2. Enantioselective epoxidation of PPh with hydrogen peroxide using a variety of possible organoactivators.

Table 1. Enantioselective epoxidation of PPh with hydrogen peroxide and other oxidants using different organocatalysts.

\begin{tabular}{|c|c|c|c|c|c|}
\hline Entry & Organocatalyst & $\begin{array}{l}\text { Catalyst amt } \\
\quad(\mathrm{mol} \%)\end{array}$ & Oxidant & Yield $^{\text {a }}(\%)$ & e.e. $b(\%)$ \\
\hline 1 & (R)-1,1'-2-naphthol & 100 & $\mathrm{H}_{2} \mathrm{O}_{2}$ & 3 & $=$ \\
\hline 2 & $(R)$-mandelic acid & 100 & $\mathrm{H}_{2} \mathrm{O}_{2}$ & 0 & $=$ \\
\hline 3 & L-proline & 100 & $\mathrm{H}_{2} \mathrm{O}_{2}$ & 0 & $=$ \\
\hline 4 & (S)-dinaphthyl-2-pyrrolidinmethanol & 100 & $\mathrm{H}_{2} \mathrm{O}_{2}$ & 6 & $=$ \\
\hline 5 & (S)-1-benzyl-3-pyrrolidinol & 100 & $\mathrm{H}_{2} \mathrm{O}_{2}$ & 0 & $=$ \\
\hline 6 & hydroquinidine 4-chlorobenzoate & 100 & $\mathrm{H}_{2} \mathrm{O}_{2}$ & 2 & $=$ \\
\hline 7 & quinine & 100 & $\mathrm{H}_{2} \mathrm{O}_{2}$ & 73 & 68 \\
\hline 8 & quinine & 50 & $\mathrm{H}_{2} \mathrm{O}_{2}$ & 42 & 67 \\
\hline 9 & quinine & 10 & $\mathrm{H}_{2} \mathrm{O}_{2}$ & 4 & $=$ \\
\hline 10 & quinine & 100 & $t-\mathrm{BuOOH}$ & 0 & $=$ \\
\hline 11 & quinine & 100 & urea. $\mathrm{H}_{2} \mathrm{O}_{2}$ & $>99$ & 20 \\
\hline 12 & sparteine & 100 & $\mathrm{H}_{2} \mathrm{O}_{2}$ & 90 & 94 \\
\hline 13 & sparteine & 50 & $\mathrm{H}_{2} \mathrm{O}_{2}$ & 43 & 96 \\
\hline 14 & sparteine & 20 & $\mathrm{H}_{2} \mathrm{O}_{2}$ & 36 & 94 \\
\hline 15 & sparteine & 100 & $t-\mathrm{BuOOH}$ & 0 & $=$ \\
\hline 16 & sparteine & 100 & urea $\cdot \mathrm{H}_{2} \mathrm{O}_{2}$ & $>99$ & 13 \\
\hline
\end{tabular}

Experimental conditions: PPh $0.080 \mathrm{mmol}$, oxidant $0.096 \mathrm{mmol}, \mathrm{CH}_{2} \mathrm{Cl}_{2} 2 \mathrm{~mL}, \mathrm{~T} 25^{\circ} \mathrm{C}$, reaction time $18 \mathrm{~h}$. ${ }^{a}$ Determined by GC analysis; ${ }^{b}$ Determined by chiral HPLC.

With quinine as the catalyst, an interesting $68 \%$ ee was observed, while the yield was strongly dependent on the amount of catalyst loaded (entries 7-9). The same effect was observed with sparteine (entries 12-14), suggesting that a stoichiometric amount of the tertiary amine activator is necessary to speed the reaction up. Under these circumstances, the "catalysts" reported in Table 1 would be better termed "activators".

Other oxidants tested were either ineffective $(t$-BuOOH, entries 10,15$)$ or very effective such as the organosoluble urea $\cdot \mathrm{H}_{2} \mathrm{O}_{2}$ adduct that led to slightly higher yields but, more importantly, with a 
significant loss of enantioselectivity (entries 11,16). A blank reaction under the same conditions but without sparteine to check whether urea alone could be a possible activator for the reaction yielded no products even after $18 \mathrm{~h}$. Similarly, the use of urea $\cdot \mathrm{H}_{2} \mathrm{O}_{2}$ (with urea as the H-bond acceptor) associated with (S)-1-benzyl-3-pyrrolidinol (as the base) gave no results in the epoxidation reaction, indicating that probably for steric reasons the basic character and the $\mathrm{H}$-bond acceptor role must coexist in the same molecule.

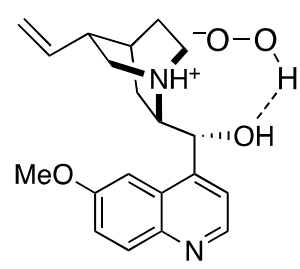

quinine

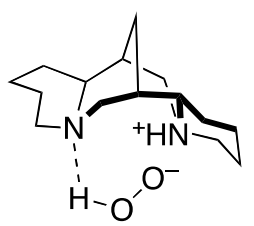

sparteine

Figure 2. Activation of hydrogen peroxide by quinine and sparteine evidencing the ion pairing and hydrogen bonding stabilization of $\mathrm{HOO}^{-}$by the activator.

Sparteine seems to be the best activator tested, capable of giving better yields, probably due to a better approach to the prochiral substrate because of a lower steric hindrance, as was further demonstrated by a full reaction profile showing that the reaction was completed in slightly more than $1 \mathrm{~h}$ (see Supplementary Material, Figure S1). Similarly, the higher ee values observed probably rely on its ability to create a more rigid and stable adduct with $\mathrm{HOO}^{-}$, thus favoring the stereoselective recognition of either face of the $\mathrm{C}=\mathrm{C}$ double bond in $\mathbf{P P h}$. The drop in enantioselectivity observed with urea $\cdot \mathrm{H}_{2} \mathrm{O}_{2}$ seems to suggest some loss of the intramolecular $\mathrm{H}$-bond, broken by the presence of urea as an external H-bond acceptor.

The good results observed with sparteine led to the extension of the above experimental procedure to the VBP structures reported in Scheme 1. In Table 2 we report the results obtained in the enantioselective epoxidation of the different prochiral precursors with hydrogen peroxide promoted by sparteine.

Table 2. Enantioselective epoxidation of prochiral VBPs with hydrogen peroxide promoted by sparteine.

\begin{tabular}{|c|c|c|c|c|}
\hline Entry & Epoxide & Acronym & Yield $^{a}(\%)$ & $\mathrm{Ee}^{\mathrm{b}}(\%)$ \\
\hline 1 & & PoOMeO & 63 & 4 \\
\hline 2 & & PmOMeO & 74 & 81 \\
\hline 3 & & PpOMeO & 77 & 1 \\
\hline
\end{tabular}


Table 2. Cont.

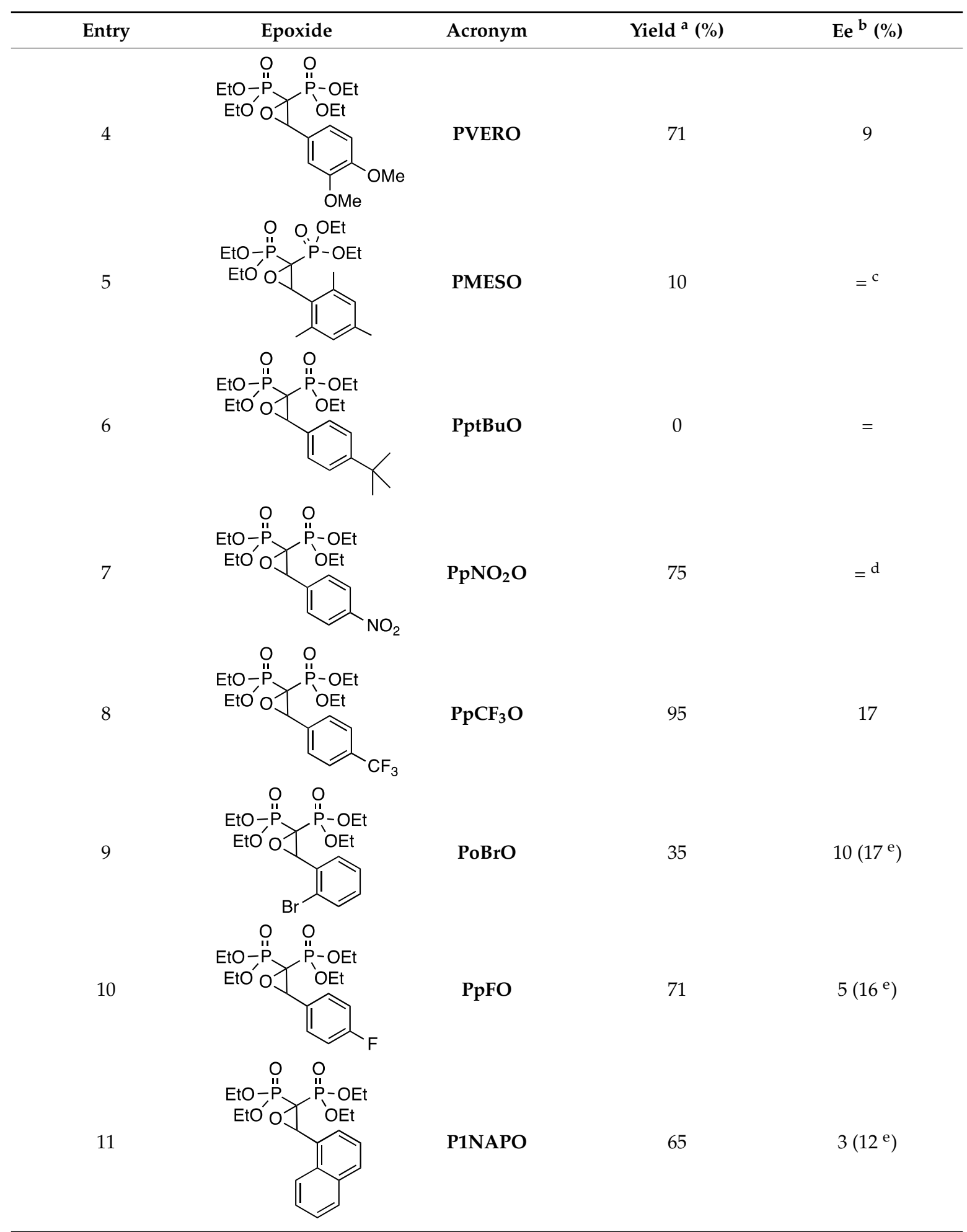

Experimental conditions: substrate $0.080 \mathrm{mmol}$, oxidant $0.096 \mathrm{mmol}$, sparteine $0.080 \mathrm{mmol}, \mathrm{CH}_{2} \mathrm{Cl}_{2} 2 \mathrm{~mL}, \mathrm{~T} 25^{\circ} \mathrm{C}$, reaction time $18 \mathrm{~h} .{ }^{\mathrm{a}}$ Determined by ${ }^{31} \mathrm{P}\left\{{ }^{1} \mathrm{H}\right\}$ NMR analysis; ${ }^{\mathrm{b}}$ Determined by chiral HPLC; ${ }^{\mathrm{c}}$ Not determined because of poor yield; ${ }^{\mathrm{d}}$ The enantiomers could not be separated; ${ }^{\mathrm{e}}$ Reaction carried out at $0{ }^{\circ} \mathrm{C}$.

First of all, it must be pointed out that some HPLC analytical problems have been found (e.g., entry 7). In this respect, some examples of successful and unsuccessful HPLC separations are reported in the Supplementary Materials. In general, sparteine promoting the epoxidation of 
aromatic MBPs appears to produce (with some exceptions) from good to excellent chemical yields, while in terms of enantioselectivity it is much less rewarding. The reaction seems to be sensitive mostly to steric factors, for example the presence of a substituent group (both electron withdrawing and electron releasing) on the aromatic ring leads to a general decrease of the reaction yields, the latter being more pronounced when the substituent is in the ortho position (Table 2, entries 1, 5, 9). The reaction is similarly inhibited by very bulky substituents even if in the para position (entry 6), indicating a difficulty of approach between the substrate $\mathrm{C}=\mathrm{C}$ double bond and the base- $\mathrm{H}_{2} \mathrm{O}_{2}$ adduct. With respect to the enantioselectivity, while with PPh the reaction showed excellent results (Table 1 , entry 12), with the naphthyl derivative (Table 2 entry 11) the ee dropped dramatically. Decreasing the reaction temperature to $0{ }^{\circ} \mathrm{C}$ produced only modest improvements (Table 2, entries 9-11). Altogether, the use of sparteine as an enantioselective activator for the epoxidation of a variety of VBPs seems to be successfully applicable preferentially to precursors such as PPh (ee $94 \%$ ) or to the corresponding $m$-MeO- derivative (PmOMe) (ee $81 \%$ ). In all other cases tested, ee values were very low.

Since the synthesized epoxides have a significant electrophilic character at the C-2 position, they could, in principle, react with a wide range of nucleophiles [35,36]. Hence, the epoxides obtained in their racemic form were tested towards sulfur-containing nucleophiles and organometals. This should lead, in principle, to BPs having an extra $\mathrm{OH}$ group on the $\mathrm{C}$ atom between the two $\mathrm{P}$ atoms, a factor known to improve their affinity for hydroxyapatite [22]. The epoxide coming from PPh (PPhO) was reacted with a stoichiometric amount of organometals such as $n$-BuLi or $\mathrm{PhMgBr}$, leading to the complete consumption of the starting PPhO epoxide and the appearance of a product whose ${ }^{31} \mathrm{P}\left\{{ }^{1} \mathrm{H}\right\}$ NMR spectrum showed two clearly different ${ }^{31} \mathrm{P}$ singlet resonances, one at $20.95 \mathrm{ppm}$ and one at -1.51 $\mathrm{ppm}$. The large up-field shift of one of the two $\mathrm{P}$ atoms is not compatible with the typical chemical shift for phosphonate units, but rather in agreement with the presence of a phosphate group [37].

The same PPhO epoxide was reacted with both thiophenol and the nucleophilically stronger potassium thiophenate without producing the ring-opening derivative and leaving a large amount of unreacted epoxide behind despite the long reaction time.

\section{Materials and Methods}

${ }^{1} \mathrm{H}$ NMR, ${ }^{31} \mathrm{P}\left\{{ }^{1} \mathrm{H}\right\}$ NMR spectra were run on: (i) a Bruker Avance 300 spectrometer (Bruker Italia, Milano, Italy) operating at 300, $122 \mathrm{MHz}$, respectively, at $298 \mathrm{~K}$; (ii) a Bruker Avance 400 spectrometer (Bruker Italia, Milano, Italy) operating at 400 and $162 \mathrm{MHz}$, respectively, at $298 \mathrm{~K} ; \delta$ values in ppm are relative to $\mathrm{Si}\left(\mathrm{CH}_{3}\right)_{4}$ and $85 \% \mathrm{H}_{3} \mathrm{PO}_{4}$.

GC-MS analyses were performed on a GC Trace GC 2000 (ThermoQuest Italia, Milano, Italy) coupled with a quadrupole MS Thermo Finnigan Trace MS with Full Scan method.

HPLC analyses were performed on a Hewlett Packard Series 1100 G1311A QuatPump (Agilent Technologies Italia, Cernusco sul Naviglio, Italy).

Flash chromatography was performed on 230-400 mesh silica and thin layer chromatography was carried out on $20 \mathrm{~cm} \times 20 \mathrm{~cm}$ Alugram ${ }^{\circledR}$ Xtra SIL G/UV 254 from Macherey-Nagel. The solvent used was ethyl acetate.

Diethyl phosphite, the aromatic aldehydes, thiophenol and potassium thiophenate, $n$-BuLi and $\mathrm{PhMgBr}$ used as reactants were commercial products (Sigma-Aldrich, Milano, Italy) and were used without any purification. All synthetic work was carried out without the exclusion of atmospheric oxygen. Solvents were dried and purified according to standard methods.

\subsection{Synthesis of Methylenebisphosphonate Tetraethyl Ester (MBP) [38]}

A sodium ethoxide solution was prepared by addition of metallic sodium (5 g, $220 \mathrm{mmol})$ in portions to ethanol $(130 \mathrm{~mL})$. Diethyl phosphite $(220 \mathrm{mmol})$ was then added with stirring to the sodium ethoxide solution, the resulting mixture was stirred for $1 \mathrm{~h}$ at $\mathrm{RT}$ and finally concentrated on a rotary evaporator. The residue was dissolved in $10 \mathrm{~mL}$ of methylene chloride $(156 \mathrm{mmol})$ and the mixture was stirred for two weeks at RT. The mixture was washed with brine, the methylene chloride phase 
was dried with sodium sulphate and brought to dryness on a rotary evaporator. The residue was distilled in vacuo to give MBP in $54 \%$ yield.

${ }^{1} \mathrm{H}$ NMR $\left(400 \mathrm{MHz}, \mathrm{CDCl}_{3}\right) \delta 4.20-4.00(\mathrm{~m}, 8 \mathrm{H}), 2.39(\mathrm{t}, J=21.0 \mathrm{~Hz}, 2 \mathrm{H}), 1.29(\mathrm{t}, J=7.1 \mathrm{~Hz}, 12 \mathrm{H})$ ppm. ${ }^{31} \mathrm{P}\left\{{ }^{1} \mathrm{H}\right\}$-NMR $\left(162 \mathrm{MHz}, \mathrm{CDCl}_{3}\right) \delta 19.38(\mathrm{~s}, 2 \mathrm{P}) \mathrm{ppm} .{ }^{13} \mathrm{C}\{1 \mathrm{H}\}-\mathrm{NMR}\left(101 \mathrm{MHz}, \mathrm{CDCl}_{3}\right) \delta 62.62$ $(\mathrm{t}, J=3.0 \mathrm{~Hz}), 25.43(\mathrm{t}, J=136.9 \mathrm{~Hz}), 16.36(\mathrm{~d}, J=3.2 \mathrm{~Hz}) \mathrm{ppm}$. GC-MS $(70 \mathrm{eV}) \mathrm{m} / \mathrm{z}: 288\left[\mathrm{M}^{+}\right], 261\left[\mathrm{M}^{+}\right.$ $\left.-\mathrm{CH}_{2} \mathrm{CH}_{3}\right], 233\left[\mathrm{M}^{+}-2\left(\mathrm{CH}_{2} \mathrm{CH}_{3}\right)\right], 205\left[\mathrm{M}^{+}-3\left(\mathrm{CH}_{2} \mathrm{CH}_{3}\right)\right]$.

\subsection{General Procedure for the Synthesis of the Mono-Substituted Alkylidene Bisphosphonates (VBPs)}

A flame-dried $50 \mathrm{~mL}$ round bottom flask equipped with a magnetic stirring bar was loaded with $\mathrm{TiCl}_{4}(15 \mathrm{mmol})$ and $3.9 \mathrm{~mL}$ of $\mathrm{CCl}_{4}$ at $0{ }^{\circ} \mathrm{C}$. Then $30 \mathrm{~mL}$ of dry THF was added dropwise to the flask and a bright yellow precipitate formed. Then the aldehyde $(5 \mathrm{mmol})$ and MBP $(5 \mathrm{mmol})$ were added followed by a $2.3 \mathrm{~mL}$ solution of 4-Methylmorpholine $(21 \mathrm{mmol})$ in $5.0 \mathrm{~mL}$ dry THF that was added dropwise to the stirred mixture over $1 \mathrm{~h}$. The reaction was allowed to warm to RT and stirred overnight. The reaction was quenched with water and extracted with EtOAc. The organic layer was washed with brine and dried over $\mathrm{Na}_{2} \mathrm{SO}_{4}$. Concentration under vacuum followed by column chromatography provided the corresponding alkylidene bisphosphonate.

The spectroscopic characterization of all compounds is reported in the Supplementary Material section.

\subsection{Epoxidation of Prochiral VBPS}

In a vial equipped with a small magnetic bar were introduced in the order: the prochiral VBP (0.080 mmol), $\mathrm{CH}_{2} \mathrm{Cl}_{2}$ as the solvent $(2.5 \mathrm{~mL})$, a $4.22 \mathrm{M}$ aqueous solution of $\mathrm{H}_{2} \mathrm{O}_{2}(0.096 \mathrm{mmol})$ and 1 equivalent of $\mathrm{KOH}$ or one equivalent of chiral activator. The reaction vessel was closed and stirred overnight at RT. The mixture obtained was purified by TLC and characterized by NMR, mass spectrometry and chiral HPLC.

\subsection{Attempts of Oxirane Ring Opening with Organometals}

In a vial equipped with a small magnetic bar were introduced $30 \mathrm{mg}$ PPhO in $1 \mathrm{~mL}$ methylene chloride followed by 1 eq. of either $n$-BuLi or $\mathrm{PhMgBr}$ at $0{ }^{\circ} \mathrm{C}$ allowing the reaction to react for $0.5 \mathrm{~h}$ then raising the temperature to RT for $1 \mathrm{~h}$. The reaction was quenched with a saturated aqueous solution of $\mathrm{NH}_{4} \mathrm{Cl}$ and extracted with EtOAc. The reaction mixture obtained was concentrated under vacuum and analyzed by NMR. Attempted purification by TLC were unsuccessful because of the high affinity of the addition products for silica.

\subsection{Oxirane Ring Opening with S-Nucleophiles}

In a vial equipped with a small magnetic bar were introduced $30 \mathrm{mg}$ PPhO in $1 \mathrm{~mL}$ methylene chloride followed by 1 eq. of either thiophenol or potassium thiophenate and the mixture was allowed to react overnight at RT. The reaction mixture obtained was concentrated under vacuum and analyzed by NMR.

\section{Conclusions}

In this paper we have demonstrated that epoxidation of aryl-substituted vinylidene bis-phosphonates accomplished with traditional methods is a viable functionalization strategy for the achievement of more elaborate molecular architectures capable of tackling the diverse facets involved in the clinical applications of this important class of drugs.

The enantioselective version of this reaction is possible using hydrogen peroxide associated with some chiral organic bases as activators (quinine, sparteine), resulting in high enantio-differentiation in just a few cases. Despite some interesting results, the general behavior of prochiral substrates reveals 
a rather elusive stereoselective course, strongly affected by somehow unpredictable steric factors in the substrate.

The new (chiral) BPs obtained via the synthetic routes outlined here are currently under study in order to investigate their biological and toxicological properties as single enantiomers to determine their cytotoxicity and their ability to induce osteoclast inhibition and apoptosis.

Supplementary Materials: The following are available online at www.mdpi.com/2073-4344/7/3/90/s1.

Acknowledgments: MIUR (PRIN 2008) and Università Ca' Foscari Venezia are gratefully acknowledged for financial support.

Author Contributions: All authors conceived and designed the experiments; A.C. performed the experiments; A.C. and L.S. analyzed the data; G.S. wrote the paper.

Conflicts of Interest: The authors declare no conflict of interest. The funding sponsors had no role in the design of the study; in the collection, analyses, or interpretation of data; in the writing of the manuscript, and in the decision to publish the results.

\section{References}

1. NIH Consensus. Development Panel on Osteoporosis Prevention, Diagnosis, and Therapy. JAMA 2001, 285, 785-795.

2. Randell, A.; Sambrook, P.N.; Nguyen, T.V.; Eisman, J.A. Direct clinical and welfare costs of osteoporotic fractures in elderly men and women. Osteoporos. Int. 1995, 5, 427-432. [CrossRef] [PubMed]

3. Melton, L.J. Hip fractures: A worldwide problem today and tomorrow. Bone 1993, 14 (Suppl. 1), S1-S8. [CrossRef]

4. Zhang, S.; Gangal, G.; Uludağ, H. 'Magic bullets' for bone diseases: Progress in rational design of bone-seeking medicinal agents. Chem. Soc. Rev. 2007, 36, 507-531. [CrossRef] [PubMed]

5. Russell, R.G.G. Bisphosphonates: The first 40 years. Bone 2011, 49, 2-19. [CrossRef] [PubMed]

6. Frith, J.C.; Monkkonen, J.; Blackburn, G.M. Clodronate and liposome-encapsulated clodronate are metabolized to a toxic ATP analog, adenosine 5' -(beta, gamma-dichloromethylene) triphosphate, by mammalian cells in vitro. J. Bone Miner. Res. 1997, 12, 1358-1367. [CrossRef] [PubMed]

7. Luckman, S.P.; Hughes, D.E.; Coxon, F.P. Nitrogen-Containing Bisphosphonates Inhibit the Mevalonate Pathway and Prevent Post-Translational Prenylation of GTP-Binding Proteins, Including Ras. J. Bone Miner. Res. 1998, 13, 581-589. [CrossRef] [PubMed]

8. Van Beek, E.; Pieterman, E.; Cohen, L. Farnesyl pyrophosphate synthase is the molecular target of nitrogen-containing bisphosphonates. Biochem. Biophys. Res. Commun. 1999, 264, 108-111. [CrossRef] [PubMed]

9. Dunford, J.E.; Rogers, M.J.; Ebetino, F.H.; Phipps, R.J. Inhibition of Protein Prenylation by Bisphosphonates Causes Sustained Activation of Rac, Cdc42, and Rho GTPases. J. Bone Miner. Res. 2006, 21, $684-694$. [CrossRef] [PubMed]

10. Gertz, B.J.; Holland, S.D.; Kline, W.F.; Quan, H. Studies of the oral bioavailability of alendronate. Clin. Pharmacol. Ther. 1995, 58, 288-298. [CrossRef]

11. Capuzzi, M.; Perdicchia, D.; Jørgensen, K.A. Highly Enantioselective Approach to Geminal Bisphosphonates by Organocatalyzed Michael-Type Addition of $\beta$-Ketoesters. Chem. Eur. J. 2007, 14, 128-135. [CrossRef] [PubMed]

12. Sulzer-Mossè, S.; Tissot, M.; Alexakis, A. First Enantioselective Organocatalytic Conjugate Addition of Aldehydes to Vinyl Phosphonates. Org. Lett. 2007, 9, 3749-3752. [CrossRef] [PubMed]

13. Barros, M.T.; Faisca Philllips, A.M. Enamine Catalysis in the Synthesis of Chiral Structural Analogues of gem-Bisphosphonates Known To Be Biologically Active. Eur. J. Org. Chem. 2008, 15, 2525-2529. [CrossRef]

14. Ebetino, F.H.; Dunford, J.E.; Lundy, M.W.; Pozzi, M.; Xia, Z.; Dobson, R. A mirror image pair of bisphosphonate analogs further demonstrates the mode of binding of the bisphosphonates in farnesyl pyrophosphate synthase. Bone 2008, 42, S36-S42. [CrossRef]

15. Chiminazzo, A.; Sperni, L.; Damuzzo, M.; Strukul, G.; Scarso, A. Copper-mediated 1,4-Conjugate Addition of Boronic Acids and Indoles to Vinylidenebisphosphonate leading to gem-Bisphosphonates as Potential Antiresorption Bone Drugs. Chem CatChem 2014, 6, 2712-2718. [CrossRef] 
16. Ferrer-Casal, M.; Barboza, A.P.; Szajnman, S.H.; Rodriguez, J.B. 1,3-Dipolar Cycloadditions of the Versatile Intermediate Tetraethyl Vinylidenebisphosphonate. Synthesis 2013, 45, 2397-2404.

17. Ruzziconi, R.; Rici, G.; Gioiello, A.; Couthon-Gourvès, H.; Gourvès, J.-P. First General Approach to Cyclohex-3-ene-1,1-bis(phosphonates) by Diels-Alder Cycloaddition of Tetraethyl Vinylidenebis(phosphonate) to 1,3-Dienes. J. Org. Chem. 2003, 68, 736-742. [CrossRef] [PubMed]

18. Bortolini, O.; Mulani, I.; De Nino, A.; Maiuolo, L.; Nardi, M.; Russo, B.; Avnet, S. Efficient synthesis of isoxazolidine-substituted bisphosphonates by 1,3-dipolar cycloaddition reactions. Tetrahedron 2011, 67, 5635-5641. [CrossRef]

19. Scarso, A.; Strukul, G. Transition-Metal-Catalyzed Stereoselective Oxidations in Drug and Natural Product Synthesis. In Stereoselective Synthesis of Drugs and Natural Products; Andrushko, V., Andrushko, N., Eds.; Wiley-VCH: London, UK, 2013; pp. 1043-1070.

20. Bianchini, G.; Scarso, A.; Chiminazzo, A.; Sperni, L.; Strukul, G. Water enhanced synthesis of gem-bisphosphonates via $\mathrm{Rh}(\mathrm{I})$ mediated 1,4-conjugate addition of aryl boronic acids to vinylidenebisphosphonate esters. Green Chem. 2013, 15, 656-662. [CrossRef]

21. Granchi, D.; Scarso, A.; Bianchini, G.; Chiminazzo, A.; Minto, A.; Sgarbossa, P.; Michelin, R.A.; Di Pompo, G.; Avnet, S.; Strukul, G. Low toxicity and unprecedented anti-osteoclast activity of a simple sulfur-containing gem-bisphosphonate: A comparative study. Eur. J. Med. Chem. 2013, 65, 448-455. [CrossRef] [PubMed]

22. Van Beek, E.; Löwik, C.; Que, I. Dissociation of binding and antiresorptive properties of hydroxybisphosphonates by substitution of the hydroxyl with an amino group. J. Bone Miner. Res. 1996, 11, 1492-1497. [CrossRef] [PubMed]

23. Lehnert, W. Knoevenagel kondensationen mit TiCl4/base-IV: Umsetzungen von aldehyden und ketonen mit phosphonoessigester und methylendiphosphonsäureestern. Tetrahedron 1973, 30, 301-305. [CrossRef]

24. Huang, J.; Zhao, M.; Duan, W. Palladium-catalyzed asymmetric 1,6-addition of diphenylphosphine to (4-aryl-1,3-butadienylidene)bis(phosphonates) for the synthesis of chiral phosphines. Tetrahedron Lett. 2014, $55,629-631$.

25. Xiang, H.; Qi, X.; Xie, Y.; Xub, G.; Yang, C. One-pot syntheses of novel pyrazole-containing bisphosphonate esters at room temperature. Org. Biomol. Chem. 2012, 10, 7730-7738.

26. Ding, H.; Xu, G.; Wang, J.; Zhang, Y.; Wu, X.; Xie, Y. Catechol-bisphosphonate conjugates: New types of chelators for metal intoxication therapy. Heteroat. Chem. 2004, 15, 549-555. [CrossRef]

27. Porter, M.G.; Skidmore, J. Asymmetric epoxidation of electron-deficient olefins. Chem. Commun. 2000, 14, 1215-1225. [CrossRef]

28. Díez, D.; Núñez, M.G.; Antón, A.B.; García, P.; Moro, R.F.; Garrido, N.M.; Marcos, I.S.; Basabe, P.; Urones, J.G. Asymmetric Epoxidation of Electron-Deficient Olefins. Curr. Org. Synth. 2008, 5, 186-216. [CrossRef]

29. Weitz, E.; Scheffer, A. Über die Einwirkung von alkalischem Wasserstoffsuperoxyd auf ungesättigte Verbindungen. Chem. Ber. 1921, 54, 2327-2344. [CrossRef]

30. Strukul, G.; Scarso, A. Environmentally Benign Oxidants. In Liquid Phase Oxidation via Heterogeneous Catalysis; Clerici, M.G., Kholdeeva, O., Eds.; Wiley: London, UK, 2013; pp. 1-20.

31. Wynberg, H.; Greijdanus, B. Solvent effects in homogeneous asymmetric catalysis. Chem. Commun. 1978, 10, 427-428. [CrossRef]

32. Colonna, S.; Molinari, H.; Banfi, S.; Julià, S.; Masana, J.; Alvarez, A. Synthetic enzymes—4: Highly enantioselective epoxidation by means of polyaminoacids in a triphase system: Influence of structural variations within the catalysts. Tetrahedron 1983, 39, 1635-1641. [CrossRef]

33. Baccin, C.; Gusso, A.; Pinna, F.; Strukul, G. Platinum-Catalyzed Oxidations with Hydrogen Peroxide: The (Enantioselective) Epoxidation of alpha.,beta.-Unsaturated Ketones. Organometallics 1995, 14, 1161-1167. [CrossRef]

34. Kakei, H.; Tsuji, R.; Ohshima, T.; Shibasaki, M. Catalytic Asymmetric Epoxidation of $\alpha, \beta$-Unsaturated Esters Using an Yttrium-Biphenyldiol Complex. J. Am. Chem. Soc. 2005, 127, 8962-8963. [CrossRef] [PubMed]

35. Sturtz, G.; Guervenou, J. Synthesis of Novel Functionalized gem-Bisphosphonates. Synthesis 1991, 661-662. [CrossRef]

36. Johnson, J.B. Ring opening of epoxides, aziridines and cyclic anhydrides. In Science of Synthesis, Stereoselective Synthesis; Vries, J.G., Molander, G.A., Evans, P.A., Eds.; Thieme: Stuttgart, Germany, 2011; pp. 759-827. 
37. Szajnman, S.; Linares, G.; Moro, P.; Rodriguez, J. New Insights into the Chemistry of gem-Bis(phosphonates): Unexpected Rearrangement of Michael-Type Acceptors. Eur. J. Org. Chem. 2005, 3687-3696. [CrossRef]

38. Nugent, R.A.; Murphy, M.; Schlatchter, S.T.; Dunn, C.J.; Smith, R.J.; Staite, N.D.; Galinet, L.A.; Shields, S.K.; Aspar, D.G.; Richard, K.A.; et al. Pyrazoline bisphosphonate esters as novel antiinflammatory and antiarthritic agents. J. Med. Chem. 1993, 36, 134-139. [CrossRef] [PubMed]

(C) 2017 by the authors. Licensee MDPI, Basel, Switzerland. This article is an open access article distributed under the terms and conditions of the Creative Commons Attribution (CC BY) license (http:/ / creativecommons.org/licenses/by/4.0/). 